\title{
STUDI AKTIVITAS ANTIDIABET CUKA BUAH MANGROVE PEDADA (Sonneratia alba) SECARA IN VIVO
}

\author{
Hardoko $^{a}, *$, Bambang Budi Sasmito ${ }^{a}$, Eka Nurul Fitriani ${ }^{b}$ \\ aprogram Studi Teknologi Hasil Perikanan, Jl. Veteran No. 1 Malang 65145, Indonesia \\ *Koresponden penulis : hardoko@ub.ac.id
}

\begin{abstract}
Abstrak
Aktivitas anti diabetes suatu bahan dapat dipelajari secara invitro menggunakan enzim atau invivo menggunakan tikus percobaan. Penelitian ini bertujuan untuk mempelajari aktivitas antidiabet dari cuka buah mangrove pedada dalam menurunkan gula darah tikus putih yang dibuat diabetes. Metode penelitian yang digunakan adalah metode eksperimen menggunakan perlakuan dosis pemberian cuka buah $(0,2 ; 0,4$; 0,6 mL tikus/hari, kontrol positif, kontrol negatif) dan lama pemberian cuka buah (0, 7, 14 dan 21 hari) pada tikus putih diabetes. Hasilnya menunjukkan bahwa cuka buah pedada mampu menurunkan glukosa darah tikus diabetes. Kemampuan cuka buah pedada dalam menurunkan glukosa darah tikus diabetes dipengaruhi oleh dosis dan lama pemberian cuka buah pedada. Dosis pemberian cuka pedada pada tikus diabet yang hasilnya sama obat glibenklamid (kontrol + ) adalah $0,4 \mathrm{~mL}$ tikus/hari dengan lama pemberian 14 hari.
\end{abstract}

Kata kunci : cuka, diabetes, dosis, glukosa darah, buah pedada

\begin{abstract}
Antidiabetic activity of a substance can be studied in vitro using an enzyme or in vivo using rats. This research aimed to study the antidiabetic activity of mangrove fruit vinegar in reducing the blood glucose of diabetic white rats. The research method used was an experimental method with treatment of fruit vinegar dose $(0.2 ; 0.4 ; 0.6 \mathrm{~mL} / \mathrm{rat} /$ day, positive control, negative control) and duration of fruit vinegar administration ( $0,7,14$ and 21 days) on diabetic white rat. Results showed that pedada fruit vinegar was able to reduce the blood glucose of diabetic rats. The ability of vinegar to reduce blood glucose on diabetic rats was influenced by the dose and duration of administration of fruit vinegar. The dose of vinegar administration on the diabetic rats which gave the similar results to the drug glibenclamide (positive control) was $0.4 \mathrm{~mL} / \mathrm{rat} / \mathrm{day}$ with a duration of administration of 14 days.
\end{abstract}

Keywords : blood glucose, diabetic, dose, pedada fruit, vinegar

\section{PENDAHULUAN}

Diabetes Mellitus (DM) merupakan salah satu penyakit degeneratif yang menjadi ancaman utama bagi kesehatan manusia. Penyakit DM merupakan keadaan hiperglikemia kronik disertai berbagai kelainan metabolik akibat gangguan hormonal. Penyebabnya ialah berkurangnya produksi hormon insulin yang dihasilkan oleh sel-sel beta di kelenjar pankreas. Kerusakan sel-sel beta pankreas menyebabkan tubuh kurang bisa menghasilkan insulin sehingga menyebabkan kadar glukosa darah meningkat [1].

Pengobatan DM yang telah dilakukan ialah injeksi insulin dan pemberian obat oral anti diabetes (OAD). Namun, metode tersebut memerlukan biaya yang besar dan beresiko menimbulkan efek samping. Mahalnya biaya pengobatan DM memicu pencarian obat alternatif dari bahan alami yang dapat dijangkau oleh masyarakat serta memiliki efek samping minimal dibandingkan pengobatan kimia [2].

Tumbuhan mangrove memiliki potensi sebagai bahan obat yang besar. Tumbuhan ini kaya akan steroid, triterpen, saponin, flavonoid, alkaloid, dan tanin. Secara tradisional, kandungan bioaktif tumbuhan mangrove banyak digunakan sebagai bahan obat yang mencakup anti helmintik, anti mikrobia, anti jamur, anti kanker, anti tumor, anti diare, pendarahan, analgesik, inflamasi, disinfektan, serta anti oksidan, anti hiperglisemik, dan astringen [3]. 
Mangrove adalah individu jenis tumbuhan maupun komunitas tumbuhan yang tumbuh di daerah pasang surut [4] dengan kondisi lingkungan peralihan. Kondisi lingkungan perlaihan ini diduga mengakibatkan tanaman mangrove menghasilkan metabolit sekunder untuk pertahanan diri pada lingkungan peralihan. Metabolit sekunder itulah yang dapat digunakan sebagai bahan aktif yang berguna untuk obat dan kesehatan. Salah satu jenis mangrove yang sudah banyak dimanfaatkan oleh masyarakat Surabaya adalah Sonneratia alba [5]. Mangrove Sonneratia alba memiliki 24 metabolit sekunder yang baik untuk kesehatan yaitu 8 steroid, 9 triterpen, 3 flavonoid dan 4 turunan karboksil benzene [6]. Sonneratia alba telah dimanfaatkan sebagai produk dodol, wajik, permen dan sirup.

Buah pedada bentuknya bulat lonjong seperti buah apel, sehingga sering disebut 'apel mangrove'. Salah satu produk dari buah apel yang bermanfaat untuk kesehatan adalah cuka buah apel. Cuka apel (Apple Cider Vinegar) adalah cairan fermentasi buah apel yang difermentasi oleh khamir dan bakteri asam asetat [7]. Pada cuka apel terdapat kandungan asam asetat, tanin dan flavonoid yang dapat memberikan pengaruh terhadap kadar glukosa darah. Pemberian cuka salak $0.4 \mathrm{ml} /$ tikus dan cuka apel $0.4 \mathrm{ml} /$ tikus berpengaruh nyata pada penurunan kadar glukosa darah tikus diabetes mellitus [8].

Melihat adanya manfaat dari cuka apel dan cuka salak, maka buah-buah yang lainpun juga dapat dibuat menjadi cuka buah, khususnya buah-buahan yang mengandung gula seperti anggur, pisang, apel, dan lain-lain [9]. Cuka buah mengandung cita rasa, zat warna dan substansi yang terekstrak, asam buah, garam-garam organik dari buah yang berbeda-beda sesuai dengan asalnya [10]. Cuka apel diproses melalui pengekstrakan sari buah apel sebagai substrat fermentasi alkohol. Fermentasi cuka buah menghasilkan kandungan senyawa yang bermanfaat sebagai pencegahan atau meminimalkan terjadinya suatu penyakit [11].

Buah pedada mempunyai metabolit sekunder yang lebih bervariasi daripada buah apel. Apabila buah pedada dibuat menjadi cuka buah maka timbul dugan akan mempunyai manfaat yang sama atau bahkan lebih baik dari cuka apel. Oleh karena itu perlu dilakukan penelitian untuk pengembangan produk buah pedada yang bermanfaat untuk kesehatan penderita diabetes. Penelitian kali ini dilakukan dengan tujuan untuk mengetahui aktivitas antidiabetes cuka pedada secara invivo pada tikus percobaan dibandingkan dengan obat antidiabetes glibenklamid. Dengan demikian diketahui potensi cuka pedada sebagai bahan pangan fungsional antidiabetes.

\section{MATERI DAN METODA}

\section{Bahan dan alat}

Bahan yang diteliti adalah cuka buah yang dibuat dari buah pedada (Sonneratia alba) tua yang diperoleh dari UKM Kawasan Konservasi Mangrove Kota Bontang, Kalimantan Timur, gula pasir, dan mikroba Sacharomyces cerevisiae serta Acetobacter acetii dari Laboratorium Teknologi Pangan UB. Bahan-bahan yang digunakan untuk analisis kimia yaitu magnesium (Merck), amil alkohol (Merck), asam galat (Aldrich), etanol (Merck), reagen Folin Ciocalteau (Merck), $\mathrm{Na}_{2} \mathrm{CO}_{3}$ (Merck), aquades, reagen kit glucose GOD PAP (Diasys Germany), obat diabetis glibenclamide $5 \mathrm{mg}$, dan Alloxsan Monohydrate (Sigma Aldrich).

Bahan-bahan yang digunakan dalam pembuatan ransum tikus adalah tepung jagung, kasein, minyak jagung, campuran mineral, campuran vitamin, selulosa, dan air yang diperoleh dari Laboratorium Gizi, Departemen Gizi Kesehatan, Fakultas Kesehatan Masyarakat Universitas Airlangga Surabaya. Komposisi ransum tikus disesuaikan dengan standar [12] AOAC (2005), terdiri dari karbohidrat $70 \%$, protein $10 \%$, lemak $8 \%$, mineral $5 \%$, serat $1 \%$, vitamin $1 \%$, dan air $5 \%$ yang dirinci seperti Tabel 1.

Tabel 1. Formula ransum tikus

\begin{tabular}{lc}
\hline Bahan & Jumlah $(\mathbf{g})$ \\
\hline Tepung jagung & 70,52 \\
Kasein & 11,48 \\
Minyak jagung & 7,76 \\
Campuran mineral & 4,47 \\
Campuran vitamin & 1 \\
Selulosa & 1 \\
\hline
\end{tabular}


Air

4,31

Adapun alat yang digunakan terdiri dari tikus wistar putih (Rattus novergicus) berjenis kelamin jantan, berumur 2,5- 3 bulan dengan berat badan 100-200g (dari Laboratorium Gizi Departemen Gizi Kesehatan Fakultas Kesehatan Masyarakat Universitas Airlangga, Surabaya) dan perlengkapannya (kandang dan peralatan makan dan minum), peralatan untuk pembuatan cuka buah mangrove (nampan, baskom, pisau, panci, kompor, termometer, blender, timbangan digital, beaker glass, penyaring, fermentor, selang, neraca analitik Ohaus, buret, labu ukur, alat suling, timbangan digital, termometer, $\mathrm{pH}$ meter, pipet volume, pipet tetes, bola hisap, dan tabung reaksi), peralatan analisis kimia (beaker glass, pipet volume, bola hisap, timbangan digital, sendok bahan, tabung reaksi, rak tabung reaksi, vortex, dan spektrofotometer), alat injeksi aloksan (syringer/spet $1 \mathrm{ml}$ ), dan alat analisis kadar glukosa darah (sentrifuge, pipet tetes, tabung reaksi, rak tabung reaksi, mikro pipet, mikro kuvet dan spektrofotometer).

\section{Metode Penelitian}

Metode yang digunakan dalam penelitian ini adalah metode eksperimen melalui tahapan pembuatan cuka buah pedada, pembuatan tikus diabet, dan percobaan pemberian dosis cuka buah pedada $(0 ; 0,2 ; 0,4 ;$ dan 0,6 $\mathrm{mg} / \mathrm{tikus}$ /hari, dan kontrol positif menggunakan obat glibenklamid 0,09 $\mathrm{mg} / \mathrm{tikus} /$ hari) dan lama pemberian cuka buah pedada $(0 ; 7 ; 14 ;$ dan 21 hari) pada tikus diabet. Perlakuan yang diberikan mengacu pada penelitian [13] yang merupakan hasil konversi dari manusia ke tikus dengan faktor konversi 0.0054 dan penelitian [14] untuk cuka salak $(0,4 \quad \mathrm{ml} /$ tikus/hari dan 0,7 $\mathrm{ml} /$ tikus/hari dengan lama pemberian selama 28 hari). Percobaan pada penelitian ini telah mendapatkan surat keterangan kelaikan etik dari komisi etik kelaikan UB No. 1098-KEPUB.

\section{Pembuatan Sari Buah Mangrove Pedada}

Buah pedada dilakukan sortasi untuk memisahkan kotoran dan trimming untuk memisahkan buah dari tangkainya. Buah terpilih dikupas kulitnya, langsung dimasukan kedalam air dan dicuci hingga bersih. Buah yang sudah bersih diblasmir dengan mencelupkan buah pada air mendidih selama 10 menit [15]. Buah didinginkan hingga suhunya mencapai $\pm 27^{\circ} \mathrm{C}$ dengan cara didiamkan di suhu ruang. Buah yang sudah dingin dihancurkan dengan belnder sehingga menjadi bubur buah. Selanjutnya bubur buah ditaruh kain saring dan diperas sehingga diperoleh sari buah.

\section{Pembuatan Cuka Buah Pedada}

Proses pembuatan cuka buah pedada mengacu pada [16]. Sari buah ditambah gula dengan konsentrasi $7,5 \%, 10 \%, 12,5 \%$, dan $15 \%$ terhadap sari buah S. alba. Campuran disesuaikan pH-nya hingga 4,5 dan ditambah Saccharomyces cerevisiae $5 \% \quad \mathrm{v} / \mathrm{v}$ dan Acetobacter aceti $7 \%$ v/v, kemudian difermentasi secra anaerob fakultatif pada suhu $30^{\circ} \mathrm{C}$ dalam inkubator selama 5 hari, 7 hari dan 9 hari. Hasil fermentasi disaring dan disentrifus sehingga diperoleh cuka buah pedada, dsimpan dalam kulkas dan siap untuk dianalisis.

\section{Pembuatan Tikus Diabetes Melitus dan Pemberian Cuka Pedada}

Adaptasi tikus wistar dilakukan selama 7 hari dengan pakan standar minum secara ad libithum serta [17]. Kemudian tikus dibuat diabet dengan diinduksi aloksan melalui intravena pada dosis $65 \mathrm{mg} / \mathrm{Kg}$ BB (setelah hewan uji dipuasakan selama 8-12 jam), atau teknik intraperitoneal dan subkutan dosis yang diberikan sebanyak 2-3 kalinya [18]. Aloksan menyebabkan keadaan hiperglikemia pada hewan uji setelah 24 atau 48 jam setelah induksi yaitu diatas $200 \mathrm{mg} / \mathrm{dL}$ Kadar glukosa darah tikus normal berkisar antara 50-135 $\mathrm{mg} / \mathrm{dL}^{3}$ [19]. Kemudian tikus diabet diberi perlakuan dosis cuka buah pedada $(0 ; 0,2 ; 0,4$; dan $0,6 \mathrm{mg} /$ tikus/hari, dan kontrol positif menggunakan obat glibenklamid 0,09 $\mathrm{mg} /$ tikus/hari) dan lama pemberian cuka buah pedada $(0 ; 7 ; 14$; dan 21 hari).

\section{Parameter Analisis}


Parameter yang diamati pada penelitian ini adalah $\mathrm{pH}$ [20], flavonoid [21], total fenol [22], aktivitas antioksidan cuka pedada, dan kadar glukosa darah puasa tikus percobaan [23].

\section{HASIL DAN PEMBAHASAN}

\section{Karakteristik Cuka Buah Mangrove Pedada (Sonneratia alba)}

Cuka buah mangrove dalam penelitian ini dibuat dari sari buah mangrove pedada (Sonneratia alba). Karakteristik cuka buah mangrove pedada dapat dilihat pada Tabel 2.

Tabel 2. Karakteristik cuka buah mangrove pedada (Sonneratia alba)

\begin{tabular}{lc}
\hline Parameter & Nilai \\
\hline Nilai $\mathrm{pH} \quad 4,3$ \\
Total Fenol (mgGAE/100mL) & 400,50 \\
Total & 146,25 \\
$(\mathrm{mgQE} / 100 \mathrm{~mL}) \quad$ Flavonoid & \\
$\mathrm{IC}_{50}$ Antioksidan (ppm) & 97,50 \\
\hline
\end{tabular}

Nilai pH cuka sari buah pedada adalah 4,3, lebih rendah jika dibandingkan dengan cuka tomi-tomi yang mempunyai pH 5 [24]. Hal ini dapat disebabkan oleh perbedaan aktivitas $S$. cereviase dalam memecah menjadi alkohol dan gula dalam fermentasi. Makin tinggi aktivitas $S$. cerevisae makin tingi juga kadar alkohol yang dihasilkan. Kadar alkohol yang tinggi tersebut kemudian difermentasi oleh bakteri $A$. acetii menjadi asam asetat yang akan mempengaruhi perubahan $\mathrm{pH}$ cuka.

Kandungan flavonoid pada cuka sari buah mangrove pedada adalah 146,25 $\mathrm{mgQE} / 100 \mathrm{~mL}$ lebih tinggi apabila dibandingkan flavonoid pada cuka salak sebesar $1315 \mathrm{mg} / \mathrm{L}$ [2]. Flavonoid merupakan senyawa fenolik yang potensial sebagai antioksidan dan mempunyai bioaktifitas sebagai obat. Senyawa flavonoid dapat berfungsi sebagai antioksidan, antidiabetik, antikanker, antiseptik, dan anti-inflamasi [25]. Flavonoid meningkatkan jalur glikolitik dan glikogenik dengan menekan jalur glikogenolisis dan glukoneogenesis yang akan menyebabkan glukosa darah dapat terkendali sehingga kadar glukosa darah menurun. Aktivitas antioksidan senyawa flavonoid dapat mencegah dan mengurangi penumpukan lemak di dalam tubuh sehingga mampu mengobati masalah obesitas yang merupakan faktor penyebab penyakit diabetes melitus [26].

Kandungan total fenol cuka buah mangrove pedada sebesar 400,50 mgGAE/100 $\mathrm{mL}$ lebih tinggi jika dibandingkan kandungan total fenol pada cuka salak $(229,67 \mathrm{mg} / \mathrm{L})$ [13] dan juga kandungan total fenol pada cuka apel $(135,38 \mathrm{mg} / \mathrm{L})$. Menurut [27], kandungan total fenol memiliki korelasi yang kuat dengan aktivitas antioksidan, dimana apabila total fenol memiliki nilai yang tinggi maka aktivitas antioksidan cenderung meningkat. [28] melaporkan bahwa polifenol juga dapat menurunkan gula darah.

Aktivitas antioksidan pada cuka sari buah mangrove pedada (Sonneratia alba) dengan nilai $\mathrm{IC}_{50}$ sebesar 97,50 ppm. Berdasarkan hasil tersebut dapat dikatakan cuka buah mangrove pedada (Sonneratia alba) memiliki aktivitas antioksidan yang kuat. Namun Aktivitas tersebut masih lebih rendah jika dibandingkan dengan penelitian [29], yaitu minuman teh daun alpukat (Persea americana miller) yang memiliki kadar antioksidan tertinggi dengan nilai $\mathrm{IC}_{50} 24,86$ ppm. Buah yang memiliki kandungan fenolik tinggi berpotensi memiliki aktivitas antioksidan yang tinggi [30].

\section{Pengaruh Cuka Buah Mangrove Pedada (Sonneratia alba) Terhadap Glukosa Darah Tikus Wistar Hiperglikemia}

Dalam penelitian ini, tikus dipuasakan selama 12 jam sebelum pemberian analisis gula darah dengan tujuan untuk menjaga agar kadar glukosa darah stabil. Hal ini sesuai dengan penelitian [31], bahwa tikus perlu dipuasakan selama 10-14 jam sebelum pengambilan darah. Hasil ANOVA kadar glukosa darah, menunjukkan perlakuan dosis dan lama hari pengamatan, serta interaksi dari keduanya berpengaruh nyata $(\mathrm{p}<0,05)$ terhadap kadar glukosa darah tikus. Hasil uji lanjut Duncan dapat dilihat pada Gambar 1. 


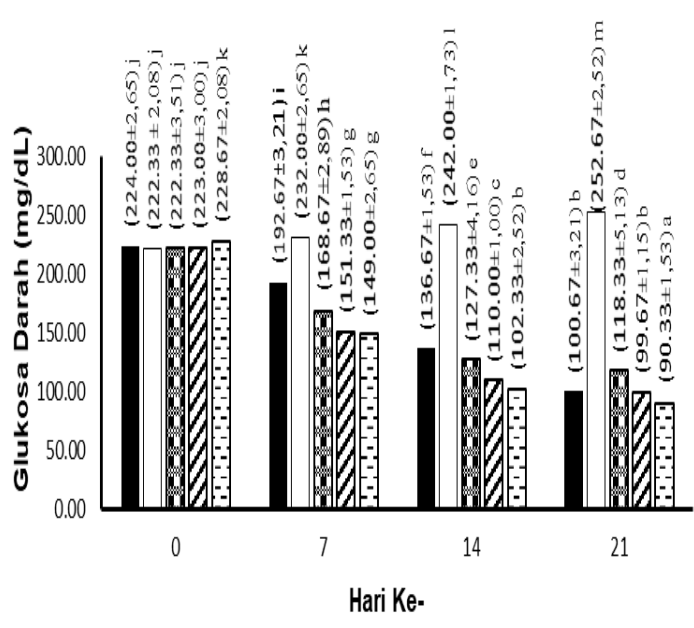

- Kontrol + पKontrol - $0,2 \mathrm{ml} /$ tikus/hari $\mathbf{0} 0,4 \mathrm{ml} /$ tikus/hari $\mathbf{0} 0,6 \mathrm{ml} /$ tikus/ hari

Keterangan: Notasi huruf menunjukkan beda nyata $(p<0,05)$

Gambar 1. Histogram kadar glukosa darah tikus selama 21 hari

Pada Gambar 1 terlihat bahwa semua perlakuan dengan pemberian cuka sari buah mangrove pedada dapat menurunkan kadar glukosa darah secara bertahap selama 21 hari pengamatan. Penurunan kadar glukosa darah yang berbeda pada setiap perlakuan dosis terkait dengan jumlah bioaktif seperti total fenolik dan flavonoid yang berbeda pula (Tabel 2). Pada dosis yang lebih tinggi maka bioaktifnya juga lebih tinggi dan efeknya ke gula darah juga lebih besar. Senyawa fenolik, dan flavonoid merupakan senyawa antioksidan yang berperan aktif dalam penangkapan radikal bebas. Sifat antioksidan senyawa fenolik, dan flavonoid dikarenakan sifat kimianya dimana fenolik, dan flavonoid dapat berperan sebagai agen pereduksi, pendonor atom hidrogen, pengkelat logam serta memiliki aktivitas biologis yang dapat membantu memelihara sistem metabolisme tubuh [32]. [33] dan [34] melaporkan bahwa dosis dalam pemberian ekstrak tepung buah bakau (Rhizopora mucronata) yang paling optimal adalah $750 \mathrm{ppm}$ dan akan didapatkan kadar glukosa darah tikus normal pada hari ke-20. Hal ini menunjukkan bahwa pada dosis yang lebih tinggi diduga mengandung senyawa bioaktif yang lebih banyak, sehingga dapat menurunkan kadar glukosa lebih besar.

Tikus yang diberikan dosis cuka sari buah mangrove $0,2 \mathrm{~mL} /$ tikus/hari mengalami penurunan kadar glukosa darah dari 222,33 $\mathrm{mg} / \mathrm{dL}$ pada hari ke- 0 menjadi $118,33 \mathrm{mg} / \mathrm{dL}$ pada hari ke-21. Pada tikus yang diberikan dosis $0,4 \mathrm{~mL} / \mathrm{tikus} /$ hari mengalami penurunan kadar glukosa darah dari $223,00 \mathrm{mg} / \mathrm{dL}$ pada hari ke-0 menjadi 99,67 mg/dL pada hari ke21. Tikus dengan pemberian cuka sari buah mangrove dosis $0,6 \mathrm{~mL} /$ tikus/hari mengalami penurunan kadar glukosa darah dari 228,67 $\mathrm{mg} / \mathrm{dL}$ pada hari $\mathrm{ke}-0$ menjadi $90,33 \mathrm{mg} / \mathrm{dL}$ pada hari ke-21. Fenomena tersebut mengindikasikan bahwa cuka buah pedada berpotensi sebagai penurun gula darah diabetes melitus atau antidiabet.

Pada histogram kontrol (+) (obat glibenclamide dosis $0,09 \mathrm{mg} / \mathrm{tikus} / \mathrm{hari})$ mengalami penurunan kadar glukosa darah dari $224,00 \mathrm{mg} / \mathrm{dL}$ pada hari ke-0 menjadi $100,67 \mathrm{mg} / \mathrm{dL}$ pada hari ke-21, sedangkan pada tikus kontrol (-), kadar glukosa darah tikus mengalami peningkatan dari 222,33 $\mathrm{mg} / \mathrm{dL}$ pada hari ke-0 menjadi $252,67 \mathrm{mg} / \mathrm{dL}$ pada hari ke-21. Hal tersebut menunjukkan bahwa obat gibenclamid efektif menurunkan gula darah diabet. Apabila dibandingkan dengan cuka buah pedada yang juga berkemampuan menurunkan gula darah (Gambar 5) maka didapatkan pemberian cuka buah pedada $0,4 \mathrm{mg} /$ tikus/hari pada hari ke 14 atau hari 21 setara dengan pemberian obat glibenklamid.

Pada cuka sari buah mangrove terkandung flavonoid dimana menurut [35], flavonoid memiliki efek biologi yang bervariasi seperti aktivitas immuno-modulasi, antioksidan, efek hipolipidemik, hipoglikemik dan melenturkan pembuluh darah. Efek antidiabetik flavon juga telah dibuktikan melalui penelitian pada tikus, bahwa flavon dapat memodulasi metabolisme lipid, glukosa abnormal, memperbaiki resistensi insulin perifer dan mengurangi komplikasi diabetes yang disebabkan oleh abnormalitas profil lipid dan resistensi insulin. Aksi flavonoid yang bermanfaat pada diabetes mellitus adalah melalui kemampuannya untuk menghindari absorpsi glukosa atau memperbaiki toleransi glukosa. Lebih lanjut flavonoid menstimulasi pengambilan glukosa pada jaringan perifer, mengatur aktivitas dan ekspresi enzim yang terlibat dalam jalur metabolisme karbohidrat dan bertindak menyerupai insulin, dengan mempengaruhi mekanisme insulin signaling. Mekanisme antidiabetes dari flavonoid menurut [36], melalui dua cara yaitu dengan 
beraktivitas menyerupai insulin dan kemampuan meningkatkan aktivitas insulin. Kemampuan flavonoid menyerupai insulin, khususnya epigallokatekin galat adalah dengan mengatur pengkodean enzim glukoneogenik dan fosforilasi protein tirosin dengan memodulasi reaksi redoks dalam sel. Kemampuan flavonid dalam meningkatkan aktivitas insulin adalah dengan meningkatkan pengambilan glukosa ke dalam jaringan adiposit. Selain itu flavonoid yang terkandung di dalam cuka sari buah mangrove pedada diduga menjadi faktor yang dapat mengendalikan glukosa darah pada tikus diabetes.

Berdasarkan data Gambar 1 dapat dibuat regresi untuk menentukan hari keberapa tikus diabet akan normal gula darahnya oleh perlakuan obat glibenclamid atau cuka buah pedada seperti terlihat pada Gambar 2 dan ditabulasikan pada Tabel 3.

Berdasarkan persamaan Gambar 2 atau Tabel 3 menunjukkan bahwa semakin besar nilai slope atau kemiringan garis maka kemampuan dalam penurunan kadar glukosa darah semakin besar. Nilai slope negatif menunjukkan penurunan dan sebaliknya nilai slope positif menunjukkan peningkatan gula darah. Nilai slope yang mempunyai kedekatan atau kemiripan dengan kontorl + adalah pemberian cuka pedada 0.4 mLtikus/hari. Dengan demikian pemberian cuka buah pedada yang berkemampuan sama dalam menurunkan gula darah tikus diabetes adalah pemberian cuka pedada 0.4 $\mathrm{ml} /$ tikus/hari.

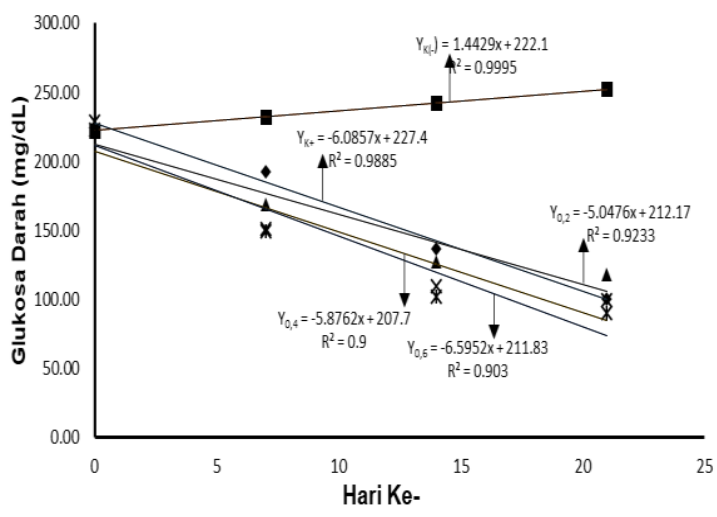

- Kontrol + \Kontrol - $\boldsymbol{\Delta} 0,2 \mathrm{ml} /$ tikus/hari $\times 0,4 \mathrm{ml} /$ tikus/hari $\boldsymbol{*} 0,6 \mathrm{ml} /$ tikus/ hari

Gambar 2. Grafik regresi hubungan dosis cuka pedada dengan gula darah tikus.
Tabel 3. Penentuan lama waktu pemberian cuka pedada untuk menormalkan gula darah dari kondisi diabetes

\begin{tabular}{llc}
\hline Perlakuan & Persamaan Regresi & $\begin{array}{c}\text { Normal } \\
\text { hari ke... }\end{array}$ \\
\cline { 2 - 3 } Kontrol $(-)$ & $Y_{K_{-}}=1,44 x+222,1$ & - \\
Kontrol $(+)$ & $Y_{K_{+}}=-6,09 x+227,4$ & 22 \\
0,2 ml/tikus/hari & $Y_{0,2}=-5,05 x+212,17$ & 24 \\
$0,4 \mathrm{ml} /$ tikus/hari & $Y_{0,4}=-5,88 x+207,7$ & 19 \\
0,6 ml/tikus/hari & $Y_{0,6}=-6,59 x+211,83$ & 17 \\
\hline
\end{tabular}

Apabila dosis pemberian dikonversikan ke manusia, perlu faktor konversi sebesar 56,0 (tikus 200 gram ke manusia $70 \mathrm{~kg}$ ) [37], sehingga dosis dari cuka sari buah mangrove pedada (Sonneratia alba) 0,4 mL/tikus/hari setara dengan $22,4 \mathrm{~mL} / 70 \mathrm{~kg} \mathrm{BB} /$ hari. Dosis tersebut terlihat agak besar, maka bisa dipilih dosis yang lebih kecil $0,2 \mathrm{~mL} /$ tikus/hari yang setara dengan $11,2 \mathrm{~mL} / 70 \mathrm{~kg} \mathrm{BB} /$ hari.

\section{KESIMPULAN}

Cuka buah mangrove pedada (Sonneratia alba) berpotensi sebagai antidiabet atau penurun gula darah diabetes yang setara dengan obat antidiabet glibenclamid.

Dosis pemberian cuka mangrove pedada yang mampu menurunkan gula darah setara dengan obat glibenklamid adalah 4,0 $\mathrm{ml} /$ tikus/hari dengan lama pemberian 14 hari.

\section{UCAPAN TERIMA KASIH}

Terima kasih kepada Fakultas Perikanan dan Ilmu Kelautan yang telah memberikan Hibah Penelitian dan Pengabdian Kepada Masyarakat melalui BPP FPIK dengan Surat No 54 tahun 2019.

\section{DAFTAR PUSTAKA}

[1] I.N. Suarsana, B.P. Priosoeryanto, M. Bintang, dan T. Wresdiyati, "Profil glukosa darah dan ultrastruktur sel beta pankreas tikus yang diinduksi senyawa aloksan," JITV, vol. 15, no. 2, hal 118123, 2010.

[2] E. Zubaidah, dan R. Indri, "Efektivitas cuka salak dan cuka apel terhadap kadar glukosa dan hispatologi pankreas tikus diabetes." Jurnal Pangan dan 
Agroindustri, vol. 4, no. 1, hal. 170179, 2016.

[3] A.D. Setyawan, dan K. Winarno, "Pemanfaatan langsung ekosistem mangrove di Jawa Tengah dan penggunaan lahan di sekitarnya: kerusakan dan upaya restorasinya," Biodiversitas, vol. 7, no. 3, hal. 282291, 2006.

[4] E. Mulyadi, H. Okik, dan F. Nur, "Konservasi hutan mangrove sebagai ekowisata," Jurnal Ilmiah Teknik Linngkungan, vol. 1, hal. 51-58, 2009.

[5] A. H. Susanto, S. Thin, dan P. Hery, "Struktur komunitas mangrove di sekitar jembatan suramadu sisi surabaya," Bioscientiae, vol. 10, no. 1, hal. 1-10, 2013.

[6] Hamsah, "Karakterisasi sifat fisikokimia tepung buah bakau (Sonneratia alba)," Skripsi. Jurusan Teknologi Pertanian. Fakultas Pertanian. Universitas Hasanuddin Makasar, hal. 22. 2013.

[7] S. Yulianti, Irlansyah., J. Edi, dan W. Mufatis, Khasiat \& manfaat apel," Jakarta : Agro Media Pustaka, 78 hal., 2007.

[8] E. Zubaidah, "Pengaruh pemberian cuka apel dan cuka salak terhadap kadar glukosa darah tikus wistar yang diberi diet tinggi gula," Jurnal Teknologi Pertanian, vol. 2, no. 13, hal. 163-169, 2011.

[9] C. Orey, "Khasiat cuka : Cairan ajaib penyembuh alami," Jakarta : Hikmah, 368 hal., 2008.

[10] E. Zubaidah, dan V. Christina, "Studi aktivitas antioksidan cuka berbasis buah anggur bali (Vitis vifera) utuh dan tanpa kulit," Jurnal Teknologi Hasil Pertanian, vol. 7. no. 2, hal 95-103, 2014.

[11] M. Nugraheni, "Potensi makanan fermentasi sebagai makanan fungsional," Yogyakarta : Seminar Nasional Wonderful Indonesia. Universitas Negeri Yogyakarta Press, 2011.

[12] AOAC (Association of Official Analytical Chemist), "Official method of analysis of the association of official analysis chemist," Washington DC (USA) : AOAC int., 2005.

[13] E. Zubaidah, dan N.F. Izzati," Efek cuka apel dan cuka salak terhadap penurunan glukosa darah dan hispatologi pankreas tikus wistar diabetes." Jurnal Kedokteran Brawijaya, vol. 28, no. 4, hal. 297-301, 2015.

[14] O.K. Hamidatun, Mandasari, I. Rosdiana, dan. S.D. Widiyana, "Pengaruh cuka salak terhadap penurunan glukosa darah dan histopatologi pankreas tikus diabetes," Program Kreativitas Mahasiswa, hal. 1-6, 2014.

[15] D. Caturryanti, S. Luwihana, dan S. Tamaroh, Pengaruh varietas apel dan campuran bakteri asam asetat terhadap proses fermentasi cider. Agritech, vol. 28, no. 2, hal. 70-75, 2008.

[16] A. Januarersti, E.T. Sutrisno, dan Y. Taufik, "Pengaruh konsentrasi inokulum acetobacter aceti dan lama fermentasi terhadap karakteristik vinegar murbei (Morus alba)." Laporan Penelitian, Jurusan Teknologi Pangan, Fakultas Teknik, Universitas Pasundan, Bandung, 2016.

[17] Hardoko, "Pengaruh konsumsi gel dan larutan rumput laut (Eucheuma cottoni) terhadap hiperkolesterolemia darah tikus wistar," Jurnal Teknologi dan Industri Pangan, vol. 19, no. 2, hal. 97104, 2008.

[18] Indralisa., Safrida., K Abdullah, dan S. Mustafa, "Profil kadar glukosa darah pada tikus setelah penyuntikan aloksan sebagai hewan model hiperglikemik," 
Jurnal EduBio Tropika, vol. 3, no. 1, hal 1-50, 2015.

[19] M.N. Cahyani, "Pengaruh pemberian ekstrak etanol rimpang temulawak (curcuma xanthorrizha roxb.) terhadap kadar glukosa darah tikus putih (rattus norvegicus) galur wistar yang diinduksi aloksan," Skripsi Universitas Tanjungpura, Pontianak, 2014.

[20] BSN (Badan Standarisasi Nasional), "SNI 06-6989.11-2004, Air dan Air Limbah - Bagian 11: Cara uji derajat keasaman $(\mathrm{pH})$ dengan menggunakan alat pH Meter," Jakarta, 2004.

[21] L.N. Wachidah, "Uji aktivitas antioksidan serta penentuan kandungan fenolat dan flavonoid total dari buah parijoto (mednilla speciosa blume)," Skripsi Universitas Islam Negeri Syarif Hidayatullah, Jakarta, 2013.

[22] R. Alfian. dan H. Susanti, "Penetapan kadar fenolik total ekstrak metanol kelopak bunga rosella merah (Hibiscus sabdariffa linn) dengan variasi tempat tumbuh secara spektrofotometri," Jurnal Ilmiah Kefarmasian, vol. 2, no. 1, hal. 73-80, 2012.

[23] Dyasis. Fluid stable diagnostic systems international glucose FS. Kit Glucose FS, hal. 30, 2016.

[24] S.J. Nendissa, B. Rachel, dan M. Nikholaus, "Pengaruh konsentrasi ragi saccharomyces cerevisiae dan lama fermentasi terhadap kualitas cuka tomitomi (Flacourtia inermis)," Jurnal Teknologi Pertanian, vol. 4, no. 2, hal. 50-55, 2015.

[25] S.V.M. Larantukan, N.L.E. Setiasih, dan S.K. Widyastuti, "Pemberian ekstrak etanol kulit batang kelor glukosa darah tikus hiperglikemia," Indonesia Medicus Veterinus, vol. 3, no. 4, hal. 292-299, 2014.
[26] P.P. Anjani, S. Andrianty, dan T.D. Widyaningsih, "Pengaruh penambahan pandan wangi dan kayu manis pada teh herbal kulit salak bagi penderita diabetes," Jurnal Pangan dan Agroindustri, vol. 3, hal. 203-214, 2015.

[27] A. Unzilarimbi, "Karakteristik antosianin ketan hitam (Oryza sativa glutinuous) hasil ekstraksi menggunakan metode ultrasonic bathpada berbagai variasi proses pengolahan," Malang : Thesis, Jurusan THP FTP Universitas Brawijaya, 2012.

[28] A. Ridwan, T.A. Raden, dan B. Anggraini, "Pengukuran efek antidiabetes polifenol (Polyphenon 60) berdasarkan kadar glukosa darah dan histologi pankreas mencit (Mus musculus l.) jantan yang dikondisikan diabetes mellitus," Jurnal Matematika \& Sains, vol. 17, no. 2, hal. 78-82, 2012.

[29] D. A. Anggorowati, G. Priandini, dan Thufail, "Potensi daun alpukat (Persea americana miller) sebagai minuman teh herbal yang kaya antioksidan," Industri Inovatif, vol. 6, no. 1, 1-7, 2016.

[30] C. Rekha, G. Poornima, M. Manasa, V. Abhipsa, Devi J.P., H.T.V Kumar, dan T.R.P. Kekuda, "Ascorbic acid, total phenol content and antioxidant activity of fresh juice of four ripe and unripe citrus fruits, Research Article. Chemical Science Transactions, vol. 1, no. 2, 303310, 2012.

[31] C. Fahri, Sutarno, dan L. Shanti, "Kadar glukosa dan kolesterol total darah tikus putih (Rattus norvegicus L.) hiperglikemik setelah pemberian ekstrak metanol akar meniran (Phyllanthus niruri L.)," Biofarmasi vol. 3, no. 1, hal. 1-6, 2005.

[32] A.D.W. Astuti, "Efektivitas pemberian ekatrak jahe merah (Zingiber officinale roscoe varr rubrum) dalam mengurangi nyeri otot pada atlet sepak takraw," Artikel Penelitian Universitas Diponegoro, Semarang, 2011. 
[33] I. P. Sari, "Pengaruh pemberian ekstrak tepung buah bakau (Rizhopora mucronata) muda kupas terhadap kadar glukosa darah tikus wistar putih (Rattus norvegicus)," Skripsi, $\quad$ Fakultas Perikanan dan Ilmu Kelautan, Universitas Brawijaya, Malang, 2014.

[34] R. Amalia, "Pengaruh pemberian tepung buah bakau (Rhizopora mucronata) tua kupas terhadap kadar glukosa darah tikus putih wistar (Rattus novergicus)," Skripsi, Fakultas Perikanan dan Ilmu Kelautan. Universitas Brawijaya. Malang, 2014.

[35] D. Novrial, H. Sulistyo, dan Setiawati, "Comparison of antidiabetic effects of honey, glibenclamide, metformin and their combination in the streptozotocin induced diabetics rat," Prosiding Seminar Nasional Kesehatan. Jurusan Kesehatan Masyarakat FKIK UNSOED, hal 1-15, 2012.
[36] E.D. Julianti, N. Nurjanah, H. Yuniati, E. Ridwan, dan E. Sahara, Pengaruh tapioka termodifikasi ekstrak teh hijau terhadap glukosa darah dan hispatologi pankreas tikus diabetes, Penelitian Gizi dan Makanan, vol. 38, no. 1, hal. 51-60, 2015.

[37] H. Atiqoh, R.S. Wardani, dan W. Meikawati. Uji antidabetik infusa kelopak bunga rosella (Hibiscus sabdariffa Lainn.) pada tikus putih jantan galur wistar yang diinduksi glukosa. Jurnal Kesehatan Masyarakat Indonesia, vol. 7, no. 1, hal. 43-50, 2011. 